\title{
A Study on Rural Women Entrepreneur in Ballia District, India
}

\author{
Pratima Sachan*, Eram Mirza, Shani Singh and Vishakha Yadav \\ Research Scholar, Deptt. of Home Science Extension, CSAUA\&T Kanpur, \\ Uttar Pradesh, India \\ *Corresponding author
}

\section{A B S T R A C T}

Nowadays entrepreneurship among women in has significantly becoming as an important player in shaping the landscape of entrepreneurship. Women Entrepreneurs may be defined as the woman or group of women

\begin{tabular}{|l|}
\hline Key w o r d s \\
Enterprise, \\
Empowerment, \\
Initiatives, \\
Women \\
\hline Article Info \\
\hline Accepted: \\
15 March 2020 \\
Available Online: \\
10 April 2020 \\
\hline \hline
\end{tabular}
who initiate, organize and co-operate a business enterprise. Entrepreneurship is now considered as the back bone of economic development which is major challenge globally felt by even the developed nations today. Such multi-dimensional platforms can serve as functional platforms and resource generation avenues for women entrepreneurs in their startup business phase. Rural Entrepreneurship amongst women has been a recent concern in rural India. This research paper mainly concerned with the women entrepreneurship situation in rural area of India. This study highlighted the current status of women entrepreneurs and their valuable contribution in sustainable economic growth of rural areas of India. This paper also focuses on the future scenario of women entrepreneurs and government initiatives for making women entrepreneurs more unbeaten. This study reveals some strategies for empowering rural women.

\section{Introduction}

Time immemorial, women are described as the better half of men. But in reality, the women in developing countries do not tally with this description. It is well known fact that women have played and continue to play a key role in conservation of basic life support systems such as land, water, flora and fauna. Women have to play a dual role, as a housewife and as income earners. Women have the burden of preparing food for the family, besides fulfilling their fundamental role of nurturing and caring for the children and tending to elderly members of the household (1). Even then they suffer from being economically and socially invisible. There is continued inequality and vulnerability of women in all fields like socioeconomic, political, education, health care, 
nutrition etc. Now a day educated women do not want to limit their lives in the four walls of the house $(2,3,4)$. The study has shown that the women business owners are making significant contributions to global economic health, national competitiveness and community commerce by bringing many assets to the global market. As per the analysis of the research study, women entrepreneurs have demonstrated the ability to build and maintain long-term relationships and networks to communicate effectively, to organize efficiently, to be fiscally conservative, and to be aware of the needs of their environment and to promote sensitivity to cultural Researchers contend that women business owners.

\section{Materials and Methods}

This study was conducted in state Uttar Pradesh. Uttar Pradesh is a state in northern India. There are 17 community development blocks in Ballia district out of which Hanumanganj block was selected for this study randomly. Out of 124 villages, six villages Umarganj, Baheri, Middha, Barwa, Amdari, and Chorhar were selected for the studies randomly. Those females have been selected as respondents who run their own enterprise. 90 respondents were selected purposively from six villages. Interview were scheduled as per the objective of study in consultation with the experts in the field of necessary data collection and pre-tested by interviewing a few respondents to test its reliability and validity then, suitable modifications were made according to the need of the study. The Frequency and percentage, Rank order, Arithmetic mean (X), Standard deviation (S.D.), Frequency percentage and rank order statistical tools were used in the study for precise and meaningful analysis and interpretation of the qualified data.

\section{Results and Discussion}

The Table 1 indicates that most of the respondents (45.00 per cent) belong to the middle age group followed by young age group 40.00 per cent and old age group observed 14.00 per cent. It can be said that mostly respondents were from middle age group, and they were more aware, active and enthusiastic for women entrepreneur.

Table 2 shows that majority of respondents were married with (85.00 per cent) and 5.00 per cent of respondents were widow. Whereas unmarried respondents were 10.00 percent. This shows that married women are more interested in entrepreneurship.

Table 3 shows that maximum of respondents (34 per cent) choose to had their own shop as an occupation followed by tailor and parlor shop 26.00 per cent, marketing of vegetables 19 per cent, dairy 14 per cent, restaurant 4.00 per cent and agriculture 1.00 per cent respectively. It could be concluded from Table 4 that majority of respondents prefer to have their own shop.

Table.1 Distribution of respondents according to age (N=90)

\begin{tabular}{|c|c|c|c|}
\hline S.No. & Category & No. of respondent & Per cent \\
\hline 1 & Young(18-35) & 36 & 40 \\
\hline 2 & Middle(36-50) & 40 & 45 \\
\hline 3 & Old(above 50) & 14 & 15 \\
\hline & Total & 90 & 100 \\
\hline
\end{tabular}


Table.2 Distribution of respondents according to marital status (N=90)

\begin{tabular}{|c|c|c|c|}
\hline S. No. & Category & No. of respondent & Per cent \\
\hline 1 & Married & 77 & 85 \\
\hline 2 & Unmarried & 9 & 10 \\
\hline 3 & Divorce /widow & 4 & 5 \\
\hline & Total & 90 & 100 \\
\hline
\end{tabular}

Table.3 Distribution of respondents according to occupation (N=90)

\begin{tabular}{|c|l|c|c|}
\hline S. No. & \multicolumn{1}{|c|}{ Category } & No. of respondent & Per cent \\
\hline 1 & Agriculture & 1 & 1 \\
\hline 2 & Marketing of vegetable & 17 & 19 \\
\hline 3 & Dairy & 12 & 14 \\
\hline 4 & Tailor and parlor & 23 & 26 \\
\hline 5 & Shop & 31 & 34 \\
\hline 6 & Restaurant & 4 & 4 \\
\hline 7 & Business & 2 & 2 \\
\hline & & 90 & 100 \\
\hline
\end{tabular}

Table.4 Distribution of respondents according to the market facility ( $\mathrm{N}=90)$

\begin{tabular}{|c|l|c|c|}
\hline S.No. & \multicolumn{1}{|c|}{ Category } & No. of respondent & Per cent \\
\hline 1 & Local market & 40 & 45 \\
\hline 2 & Own shop & 47 & 52 \\
\hline 3 & To private agent & 2 & 2 \\
\hline 4 & $\begin{array}{l}\text { Marketing co }- \\
\text { operative }\end{array}$ & 1 & 1 \\
\hline & \multicolumn{1}{|c|}{ Total } & 90 & 100 \\
\hline
\end{tabular}

Table.5 Distribution of respondents according to the position in family (N=90)

\begin{tabular}{|c|c|c|c|}
\hline S. No. & Category & No of respondent & Per cent \\
\hline 1 & Head & 5 & 5 \\
\hline 2 & Dependent on husband & 47 & 53 \\
\hline 3 & Dependent on in laws & 38 & 42 \\
\hline & Total & 90 & 100 \\
\hline
\end{tabular}

Table.6 Distribution of respondent according to production orientation (N=90)

\begin{tabular}{|c|c|c|c|}
\hline S. No. & Category & No. of respondent & Per cent \\
\hline 1 & Low & 20 & 21.43 \\
\hline 2 & Medium & 55 & 61.43 \\
\hline 3 & High & 15 & 17.14 \\
\hline & Total & 90 & 100 \\
\hline
\end{tabular}


It is evident from table 4 that majority of respondents (52.00 per cent) sell their finished product to their own shop and 45.00 per cent of respondents sell their finished product to the local market. Private agent (2.00 per cent) and marketing co- operatives are (1.00 per cent).

Table 5 shows that majority of respondents (53.00 per cent) were depend on their husband and 42.00 per cent were depend on in laws only 5.00 per cent of respondents have position of head in their family.

The result indicate that majority of the respondents (61.43 per cent) were found to have medium production orientation in various entrepreneurial activities. However 21.423 per cent had low production orientation and 17.14 per cent had high production orientation (Table 6).

In conclusion, the Indian society is shifting from conservative attitude to progressive attitude towards entrepreneurship. The study is mainly focused on problems faced by the rural women entrepreneurship in Balia district. Resent scenario is very fast changing with technology development, modernization, industrialization, urbanization, education and development. In such conditions, employment opportunity increased drastically for rural women. Entrepreneurship among rural women, no doubt improves the wealth of the nation in general and of the family in particular. Women need encouragement and support from the family members, government, society, male counterparts etc., with the right assistance from varied groups mentioned above, they can join the main stream of national economy and thereby contribute to the economic development. Government should draw up a plan so that the Indian Women Entrepreneurs can work more on empowerment through training and capacity building programs. If our universities and institutions join this resolve with increasing focus on women's business education, the future will see more women entrepreneurs. It is very true that rural entrepreneurship cannot be developed without proper training. Therefore, it is necessary to provide training to rural women to enhance their entrepreneurial skill and giving a path of success to rural women.

\section{References}

1. Kitching, B. and Woldie, A. (2004). Female Entrepreneurs in Transitional Economies: A Comparative Study of Businesswomen in Nigeria and China. Paper Presented At The Hawaii International Conference on Business, 21-24 June. Honolulu

2. Rao, P. (2002). Entrepreneurship and Economics Development, Kaniska Publishers, New Delhi.

3. Shruti and Lathwal. 2011. "Women Entrepreneurs in India." International Journal of Research in IT \& Management 1(3) http://www.mairec.org

4. Singh, A.P. and Singh, A.K. (2014). Current advances in Agricultural Sciences. 6(1), 42-45.

\section{How to cite this article:}

Pratima Sachan, Eram Mirza, Shani Singh and Vishakha Yadav. 2020. A Study on Rural Women Entrepreneur in Ballia District, India. Int.J.Curr.Microbiol.App.Sci. 9(04): 1851-1854. doi: https://doi.org/10.20546/ijcmas.2020.904.217 